\title{
SORPTION ISOTHERMS AND ISOSTERIC HEAT OF PERICARP AND ENDOSPERM TISSUES OF ARABICA COFFEE FRUIT
}

\author{
Camila de A. Dias ${ }^{1 *}$, Ednilton T. de Andrade1, Isabella A. Lemos ${ }^{1}$, Flávio M. Borém¹, \\ Ezequiel A. Barros ${ }^{1}$
}

${ }^{1 *}$ Corresponding author. Universidade Federal de Lavras/ Lavras - MG, Brasil.

E-mail: camila.almeidadias@gmail.com | ORCID ID: https://orcid.org/0000-0001-8422-7867

\section{KEYWORDS}

adsorption, Coffea arabica, desorption, hygroscopic equilibrium, mathematical modeling.

\begin{abstract}
The aim of this study was to evaluate and model the hygroscopic equilibrium and isosteric heat curves of pericarp and endosperm tissues of arabica (Coffea arabica) coffee fruit, in different temperature and relative humidity conditions. Sorption isotherms were drawn under temperatures from $20^{\circ} \mathrm{C}$ to $70^{\circ} \mathrm{C}$ and relative humidity ranging between $10 \%$ and $90 \%$ until the product reached the equilibrium water content with the environment. The experiment was set up in a $4 \times 4$ factorial scheme (four relative humidity of the drying air and three tissues of the coffee cherry pericarp + endosperm [1: exocarp + part of the mesocarp, 2: mesocarp, 3: endocarp, 4: endosperm]), in a completely randomized design, with three repetitions. The results were examined by analysis of variance and regression using the STATISTICA 5.0 statistical software. Among the analyzed models, the ones that best fit the experimental data were modified GAB, for exocarp + part of mesocarp and mesocarp, modified Henderson, for endocarp, and Sabbab for endosperm. It was observed that, for all treatments, the lower water contents required a higher amount of energy to reach the equilibrium water content, and the integral isosteric heat decreased with the increasing equilibrium water content.
\end{abstract}

\section{INTRODUCTION}

Coffee is an important source of income for the Brazilian economy, because the country has high estimates for each agricultural season, and the production technologies are improved daily. However, regarding drying technology or methodology, the country displays a deficit, making the drying stage the great bottleneck of the Brazilian coffee sector.

Although the technological development in the coffee postharvest area is well advanced, the behavior of each intrinsic coffee part during drying and how the interaction and interdependence occur are still unknown. The resistance imposed by the parts compounding the coffee fruit increases the drying time and, consequently, the energy expenditure.

The study of coffee fruit anatomy, as well as the chemical composition of each pericarp anatomic component and the endosperm, separately, can help to design new drying strategies, because it can promote a better understanding of the interdependent relationship of the components and their influence on the drying process.
Therefore, a correct drying operation requires knowledge of the relationships between the product and the surrounding air. In the case of coffee fruit, the phenomena observed are the water desorption and adsorption, because coffee fruits and beans are hygroscopic and can give water to or adsorb water from the environment (Corrêa et al., 2014).

The sorption isotherms describe the relationship between the equilibrium water content of a specific material and the relative humidity of the surrounding air at a set constant temperature (Simón et al., 2016). Water sorption isotherms are a very important tool, because they can be used to predict eventual changes that may affect the stability of agricultural products (Wani \& Kumar, 2016). Each material seeks hygroscopic balance at different speeds under different temperature and relative humidity conditions (Rosentrater \& Verbeek, 2017).

Several models had been utilized for representing sorption isotherms, and, although very well adapted to the obtained data, they typically have thermodynamic errors. However, the model development always comprises some simplification of the sorption process (Simón et al., 2015).

\footnotetext{
${ }^{1}$ Universidade Federal de Lavras/ Lavras - MG, Brasil.

Received in: 1-19-2018

Accepted in: 5-13-2019
} 
The energy required to remove the water associated with a hygroscopic material is always greater than the energy utilized to vaporize an equal amount of free water, under the same pressure and temperature conditions (Wang \& Brennan, 1991). This additional energy, a consequence of the bonding forces between water and the surface of the adsorbing substance, is known as isosteric desorption heat in the drying processes, and it is a good parameter for the estimation of the minimum required heat to remove an amount of water from the product.

According to Mulet et al. (1999), the water content at which the isosteric heat of sorption is almost identical to the latent heat of vaporization of free water is generally considered as an indicator of the free water content in the product.

Considering this, the objective of this work was to evaluate the hygroscopic equilibrium curves and the isosteric heat of pericarp and endosperm tissues of arabica coffee, under different controlled air conditions.

\section{MATERIAL AND METHODS}

This work was developed at the Agricultural Product Processing Laboratory at the Engineering Department of the Federal University of Lavras (UFLA), Lavras, MG. The experiment used coffee cherry (Coffea arabica L. cv. Catuaí Vermelho) fruits, manually harvested in a crop located in Ingaí, MG. After harvesting, the fruits were separated in water, by density difference, removing the lower-specific-mass ones (dried, hollow, damaged by berry borer, and poorly ground).

The next step was the fruit processing to obtain the coffee parts: exocarp (skin + part of mesocarp), mesocarp (mucilage), endocarp (parchment), and endosperm (beans/seed), for performing the individual drying.

Coffee fruits were peeled manually to prevent eventual damages to the exocarp and, with this procedure, the exocarp + part of mesocarp portion was obtained. After the removal of the major part of the mesocarp (mucilage), adhering to the exocarp, the exocarp was washed in running water and sieved to drain the surface water.

The mesocarp was obtained by processing the peeled beans in a centrifuge (Centriflux). No water was used during this step, to avoid any interference on the amount of obtained mesocarp. After this stage, mesocarp was filtered (plastic sieve), removing the solid impurities. The mesocarp was then placed in a petri dish dryer for proceeding with the drying process.

The endocarp was obtained by peeling the beans manually with tweezers. These beans had been previously peeled manually. However, the drying process was performed for the removed and intact endocarps only, the ones with no damage to their structure.

After removing the beans' endocarp, it was possible to obtain the endosperm. Thus, both endocarp and endosperm were placed in the dryer, in small polyester bags, for drying.

Weight determinations were made during drying, with 10-, 20-, 30-, 60-, and 120-min time intervals. The 10- and 20-min time intervals were used for exocarp + part of mesocarp, mesocarp, and endocarp, given that these tissues reached constant weight rapidly. Thus, after three consecutive weighings showing the same value, with 0 . 01-g difference, drying was terminated.

The static-gravimetric method was used to obtain the hygroscopic equilibrium water content of each pericarp (exocarp, mesocarp, and endocarp) and endosperm (bean/seed) tissue, separately of the arabica coffee, with initial water contents of 0.1246 (exocarp + part of the mesocarp), 0.1983 (mesocarp), 0.0804 (endocarp), and 0.1109 (endosperm), on a dry basis (db).

The analysis of the sorption processes utilized different temperature and relative humidity conditions. Table 1 presents the saturated saline solutions used in this work, as well as the air relative humidity provided by each saline solution as a function of the temperature.

TABLE 1. Equilibrium relative humidity (\%) of saturated saline solutions.

\begin{tabular}{cllc}
\hline Temperature $\left({ }^{\circ} \mathrm{C}\right)$ & \multicolumn{1}{c}{ Salts } & Relative Humidity \\
\hline \multirow{3}{*}{20} & Lithium Chloride & $\mathrm{LiCl}$ & $11.31 \pm 0.31$ \\
& Potassium Acetate & $\mathrm{CH}_{3} \mathrm{COOK}$ & $23.11 \pm 0.25$ \\
& Magnesium Chloride & $\mathrm{MgCl}_{2}$ & $33.07 \pm 0.18$ \\
& Magnesium Nitrate & $\mathrm{Mg}\left(\mathrm{NO}_{3}\right)$ & $54.38 \pm 0.23$ \\
& Potassium Chloride & $\mathrm{KCl}$ & $85.11 \pm 0.29$ \\
\hline \multirow{2}{*}{30} & Lithium Chloride & $\mathrm{LiCl}$ & $11.31 \pm 0.31$ \\
& Potassium Acetate & $\mathrm{CH}_{3} \mathrm{COOK}$ & $23.11 \pm 0.25$ \\
& Magnesium Chloride & $\mathrm{MgCl}_{2}$ & $33.07 \pm 0.18$ \\
& Magnesium Nitrate & $\mathrm{Mg}\left(\mathrm{NO}_{3}\right)$ & $54.38 \pm 0.23$ \\
\multirow{2}{*}{55} & Potassium Chloride & $\mathrm{KCl}$ & $85.11 \pm 0.29$ \\
& Lithium Chloride & $\mathrm{LiCl}$ & $11.03 \pm 0.23$ \\
& Magnesium Chloride & $\mathrm{MgCl}$ & $29.93 \pm 0.16$ \\
& Sodium Bromide & $\mathrm{NaBr}$ & $50.15 \pm 0.65$ \\
70 & Potassium Chloride & $\mathrm{KCl}$ & $80.70 \pm 0.35$ \\
\hline \multirow{2}{*}{70} & Lithium Chloride & $\mathrm{LiCl}$ & $10.75 \pm 0.33$ \\
& Potassium Chloride & $\mathrm{KCl}$ & $79.49 \pm 0.57$ \\
\hline
\end{tabular}


Samples were hermetically placed in a Gerbox plastic box of $50 \mathrm{~mL}$ approximately, under temperature and air relative humidity control. The pericarp and endosperm were wrapped in a permeable fabric (voile) to allow air to pass through the tissues, using three repetitions, as an average, for each treatment, with an initial weight of approximately $3 \mathrm{~g}$.

The temperatures of the experiments were set by adjusting the biochemical oxygen demand chamber and the oven; the relative humidity was obtained from the solutions used. Temperatures experienced were $20^{\circ} \mathrm{C}$, $30^{\circ} \mathrm{C}, 55^{\circ} \mathrm{C}$, and $70^{\circ} \mathrm{C}$, for approximately $168 \mathrm{~h}$, until the results of three consecutive weight determinations presented the same value, with a difference of $0.01 \mathrm{~g}$, at intervals of 10,30 , and $240 \mathrm{~min}$ and $24 \mathrm{~h}$.

The mathematical models found in the literature, representative of agricultural product hygroscopicity and used in the product analysis, were randomly chosen, as a function of ambient air temperature and relative humidity evaluation. This was a way of verifying what best fit the empirical reality of the products to better represent their isotherms. The models used are in Table 2.

TABLE 2. Mathematical models used for representing the hygroscopic equilibrium.

\begin{tabular}{ll}
\hline \multicolumn{1}{c}{ Model } & Equation \\
Chung Pfost & $\mathrm{Ue}=\mathrm{a}-\mathrm{b} * \ln [-(\mathrm{T}+\mathrm{c}) * \ln (\mathrm{RH})]$ \\
Copace & $\mathrm{Ue}=\mathrm{exp}[\mathrm{a}-(\mathrm{b} * \mathrm{~T})+(\mathrm{c} * \mathrm{RH})]$ \\
GAB modified & $\mathrm{Ue}=\frac{\mathrm{ab}(\mathrm{c} / \mathrm{T}) \mathrm{RH}}{\{[1-\mathrm{b} \mathrm{RH}][1-\mathrm{b} \mathrm{RH}+\mathrm{b}(\mathrm{c} / \mathrm{T}) \mathrm{RH}]\}}$ \\
Halsey modified & $\mathrm{Ue}=[\exp (\mathrm{a}-\mathrm{bT}) /-\ln (\mathrm{RH})]^{1 / c}$ \\
Henderson & $\mathrm{Ue}=\left[\ln (1-\mathrm{RH}) /\left(-\mathrm{a} * T_{a b s}\right)\right]^{1 / b}$ \\
Henderson modified & $\mathrm{Ue}=\{\ln (1-\mathrm{RH}) /[-\mathrm{a} *(\mathrm{~T}+\mathrm{b})]\}^{1 / c}$ \\
Oswin & $\mathrm{Ue}=(\mathrm{a}-\mathrm{b} * \mathrm{~T}) /[(1-\mathrm{RH}) / \mathrm{RH}]^{1 / c}$ \\
Sabbab & $\mathrm{Ue}=\mathrm{a}\left(R H^{b} / T^{c}\right)$ \\
Sigma Copace & $\mathrm{Ue}=\exp \{\mathrm{a}-(\mathrm{bT})+[\mathrm{c} \exp (\mathrm{RH})]\}$ \\
\hline
\end{tabular}

In which:

Ue: Equilibrium water content of the product (db);

RH: Relative humidity of the air (decimal);

T: Temperature of ambient air $\left({ }^{\circ} \mathrm{C}\right)$;

Tabs: Absolute temperature of ambient air (K),

$\mathrm{a}, \mathrm{b}, \mathrm{c}$ : Parameters depending on product nature.

The values of the liquid isosteric heat of desorption $\left(\mathrm{q}_{\mathrm{st}}\right)$ for each equilibrium water content were calculated by [eq. (10)]. Values of water activity, temperature, and equilibrium water content were obtained from the desorption isotherms of coffee pericarp and endosperm tissues, utilizing the best fit to the observed data model.

$$
\ln \left(a_{w}\right)=-\left(\frac{q_{s t}}{R}\right) \cdot \frac{1}{T}+c
$$

In which:

$\mathrm{a}_{\mathrm{w}}$ : Water activity (decimal);

$\mathrm{q}_{\mathrm{st}}$ : Liquid isosteric heat of sorption $\left(\mathrm{kJkg}^{-1}\right)$;

R: Universal gas constant $\left(8.314 \mathrm{~kJ} \mathrm{kmol}^{-1} \mathrm{~K}^{-1}\right.$, equal to $0.4619 \mathrm{kJkg}^{-1} \mathrm{~K}^{-1}$ ) for the water vapor;
T: Absolute temperature (K),

c: Model coefficient.

Equation (11) was used for calculating the values of the integral isosteric heat of desorption $\left(\mathrm{Q}_{\mathrm{st}}\right)$.

$$
Q_{s t}=q_{s t}+L=a \cdot \exp \left(-b \cdot U_{e}^{*}\right)+L
$$

In which:

$\mathrm{Q}_{\text {st: }}$ Integral isosteric heat of sorption $\left(\mathrm{kJkg}^{-1}\right)$;

$\mathrm{L}$ : Latent heat of free water vaporization $\left(\mathrm{kJkg}^{-1}\right)$;

Ue: Equilibrium water content (db),

a,b: Model coefficients. 
The latent heat of free water vaporization $\mathrm{L}$ $\left(\mathrm{kJkg}^{-1}\right)$, necessary for calculating $\mathrm{Q}_{\mathrm{st}}$, was obtained by the mean temperature $\mathrm{T}\left({ }^{\circ} \mathrm{C}\right)$ in the studied range by the following equation:

$$
L=2502.2-2.39 . T
$$

The adjustment of the mathematical models was made through nonlinear regression analyses, by the GaussNewton method, using the STATISTICA 5.0 software. The choice of the best model was a function of the following statistical parameters: estimate standard deviation (SE), relative mean error (P), and coefficient of determination $\left(\mathrm{R}^{2}\right)$. The standard deviation of the estimate and the relative mean error were calculated, respectively, by the following equations:

$$
\begin{gathered}
S E=\sqrt{\sum(Y-\hat{Y})^{2} / G L R} \\
P=\left[(100 / n) \sum|(Y-\hat{Y})| / Y\right]
\end{gathered}
$$

In which:

SE: Standard deviation of the estimate (decimal, dimensionless);

Y: Experimentally observed value (dimensionless);

$\hat{Y}$ : Model calculated value (dimensionless);

GLR: Model degrees of freedom ("No. of model parameters $-1 ")$;

P: Relative mean error (\%),

$\mathrm{n}$ : Number of observed data.

\section{RESULTS AND DISCUSSION}

For modeling the sorption isotherms of the coffee parts (exocarp + part of mesocarp, mesocarp, endocarp, and endosperm), at $20^{\circ} \mathrm{C}, 30^{\circ} \mathrm{C}, 55^{\circ} \mathrm{C}$, and $70^{\circ} \mathrm{C}$ temperatures, the final water contents were used, after reaching the hygroscopic equilibrium with the environment (Table 3).

\begin{tabular}{|c|c|c|c|c|c|c|c|c|}
\hline \multirow{2}{*}{ Water content $(\mathrm{db})$} & \multicolumn{8}{|c|}{ EXOCARP + PART OF MESOCARP } \\
\hline & $\mathrm{T}(20)$ & $\mathrm{RH}$ & $\mathrm{T}(30)$ & RH & $\mathrm{T}(55)$ & $\mathrm{RH}$ & $\mathrm{T}(70)$ & RH \\
\hline \multirow{5}{*}{$\mathrm{T}_{\mathrm{f}}$} & 0.3191 & 85.11 & 0.2995 & 83.62 & 0.2863 & 80.70 & 0.2509 & 79.49 \\
\hline & 0.2295 & 54.38 & 0.2060 & 51.40 & 0.1734 & 50.15 & 0.0572 & 10.75 \\
\hline & 0.1654 & 33.07 & 0.1415 & 32.44 & 0.1172 & 29.93 & & \\
\hline & 0.1391 & 23.11 & 0.1337 & 21.61 & 0.0488 & 11.03 & & \\
\hline & 0.1027 & 11.31 & 0.0950 & 11.28 & & & & \\
\hline & \multicolumn{8}{|c|}{ MESOCARP } \\
\hline \multirow{5}{*}{$\mathrm{T}_{\mathrm{f}}$} & 0.4597 & 85.11 & 0.4220 & 83.62 & 0.3898 & 80.70 & 0.3361 & 79.49 \\
\hline & 0.3771 & 54.38 & 0.3470 & 51.40 & 0.2708 & 50.15 & 0.0637 & 10.75 \\
\hline & 0.3303 & 33.07 & 0.2782 & 32.44 & 0.1998 & 29.93 & & \\
\hline & 0.2827 & 23.11 & 0.2354 & 21.61 & 0.0884 & 11.03 & & \\
\hline & 0.1917 & 11.31 & 0.1493 & 11.28 & & & & \\
\hline & \multicolumn{8}{|c|}{ ENDOCARP } \\
\hline \multirow{6}{*}{$\mathrm{T}_{\mathrm{f}}$} & 0.2290 & 85.11 & 0.1446 & 83.62 & 0.1271 & 80.70 & 0.1109 & 79.49 \\
\hline & 0.2045 & 54.38 & 0.1357 & 51.40 & 0.1067 & 50.15 & 0.0782 & 10.75 \\
\hline & 0.1798 & 33.07 & 0.1198 & 32.44 & 0.0896 & 29.93 & & \\
\hline & 0.1718 & 23.11 & 0.1104 & 21.61 & 0.0692 & 11.03 & & \\
\hline & 0.1543 & 11.31 & 0.0990 & 11.28 & & & & \\
\hline & \multicolumn{8}{|c|}{ ENDOSPERM } \\
\hline \multirow{5}{*}{$\mathrm{T}_{\mathrm{f}}$} & 0.2387 & 85.11 & 0.2295 & 83.62 & 0.1906 & 80.70 & 0.1821 & 79.49 \\
\hline & 0.1999 & 54.38 & 0.1844 & 51.40 & 0.1600 & 50.15 & 0.0966 & 10.75 \\
\hline & 0.1707 & 33.07 & 0.1555 & 32.44 & 0.1390 & 29.93 & & \\
\hline & 0.1579 & 23.11 & 0.1283 & 21.61 & 0.0966 & 11.03 & & \\
\hline & 0.1350 & 11.31 & 0.1122 & 11.28 & & & & \\
\hline
\end{tabular}

TABLE 3. Final water content (Tf), dry basis, of coffee parts, after reaching hygroscopic equilibrium with relative humidity $(\mathrm{RH} \%)$ and temperature $\left(\mathrm{T}^{\circ} \mathrm{C}\right)$.

Table 4 shows the coefficient of determination $\left(\mathrm{R}^{2}\right)$, relative mean error $(\mathrm{P})$, and standard deviation of the estimate (SE) values, for the different mathematical models, adjusted to the experimental data of sorption isotherms of coffee fruit parts, in different temperatures. 
TABLE 4. Coefficient of determination $\left(\mathrm{R}^{2}, \%\right)$, relative mean error $(\mathrm{P}, \%)$ and standard deviation of the estimate (SE, decimal), for the analyzed models, in modeling the sorption isotherms of coffee fruit parts.

\begin{tabular}{|c|c|c|c|}
\hline \multicolumn{4}{|c|}{ EXOCARP + PART OF MESOCARP } \\
\hline \multirow{2}{*}{ MODELS } & \multicolumn{3}{|c|}{ STATISTICAL PARAMETERS } \\
\hline & $\mathrm{R}^{2}$ & $\mathrm{P}$ & SE \\
\hline Chung Pfost & 96.81 & 5.414 & 0.019 \\
\hline Copace & 97.77 & 4.103 & 0.012 \\
\hline GAB modified & 99.55 & 1.598 & 0.006 \\
\hline Halsey modified & 98.43 & 1.760 & 0.007 \\
\hline Henderson & 95.29 & 4.692 & 0.192 \\
\hline Henderson modified & 86.72 & 9.261 & 0.289 \\
\hline Oswin & 79.62 & 17.775 & 0.518 \\
\hline Sabbab & 98.61 & 1.005 & 0.314 \\
\hline Sigma Copace & 97.75 & 4.114 & 0.013 \\
\hline \multirow[t]{2}{*}{ GAB } & 92.09 & 1.054 & 0.023 \\
\hline & \multicolumn{3}{|c|}{ MESOCARP } \\
\hline Chung Pfost & 99.40 & 1.870 & 0.009 \\
\hline Copace & 93.63 & 5.380 & 0.265 \\
\hline GAB modified & 99.72 & 1.576 & 0.007 \\
\hline Halsey modified & 96.74 & 5.136 & 0.025 \\
\hline Henderson & 88.62 & 6.521 & 0.523 \\
\hline Henderson modified & 92.33 & 2.129 & 0.106 \\
\hline Oswin & 95.87 & 4.877 & 0.439 \\
\hline Sabbab & 97.49 & 3.773 & 0.188 \\
\hline Sigma Copace & 93.34 & 5.531 & 0.265 \\
\hline \multirow[t]{2}{*}{ GAB } & 92.65 & 1.877 & 0.081 \\
\hline & \multicolumn{3}{|c|}{ ENDOCARP } \\
\hline Chung Pfost & 90.25 & 6.321 & 0.241 \\
\hline Copace & 91.33 & 3.346 & 0.324 \\
\hline GAB modified & 77.82 & 9.649 & 0.249 \\
\hline Halsey modified & 91.43 & 3.104 & 0.142 \\
\hline Henderson & 52.43 & 17.071 & 0.625 \\
\hline Henderson modified & 99.40 & 0.839 & 0.002 \\
\hline Oswin & 86.08 & 5.199 & 0.295 \\
\hline Sabbab & 95.91 & 1.434 & 0.345 \\
\hline Sigma Copace & 91.33 & 3.229 & 0.324 \\
\hline \multirow[t]{2}{*}{ GAB } & 78.30 & 2.743 & 0.005 \\
\hline & \multicolumn{3}{|c|}{ ENDOSPERM } \\
\hline Chung Pfost & 97.93 & 3.251 & 0.870 \\
\hline Copace & 97.89 & 2.527 & 0.682 \\
\hline GAB modified & 96.68 & 4.334 & 0.395 \\
\hline Halsey modified & 93.59 & 2.921 & 0.257 \\
\hline Henderson & 94.07 & 1.624 & 0.181 \\
\hline Henderson modified & 90.84 & 6.998 & 0.913 \\
\hline Oswin & 78.73 & 7.778 & 0.977 \\
\hline Sabbab & 99.04 & 0.217 & 0.006 \\
\hline Sigma Copace & 97.88 & 2.535 & 0.185 \\
\hline GAB & 93.89 & 1.146 & 0.002 \\
\hline
\end{tabular}


The adjusted models exhibited satisfactory values of the coefficient of determination $\left(\mathrm{R}^{2}>90 \%\right)$, except for the modified Henderson model (exocarp + part of the mesocarp), Oswin model (exocarp + part of the mesocarp, endocarp, and endosperm), Henderson (mesocarp and endocarp), modified GAB, and GAB (endocarp) models. All these models have a relative mean error of less than $10 \%$, the only exception being the Henderson model for exocarp + part of mesocarp and for the endocarp. The standard deviation value was satisfactory for all models, considering that an SE close to zero is ideal (Mohapatra \& Rao, 2005). These selection criteria were used for all pericarp and endosperm tissues, thus making it possible to select the model that best describes the studied process.

The best fit for exocarp + part of mesocarp was reached by the GAB-modified model. In the case of the mesocarp, the model best describing the sorption isotherms was the GAB-modified method. The Henderson-modified method offered the best fit of experimental data for the endocarp.
Observing the models used to describe the phenomenon for the endosperm, except for the Oswin model, all other models presented satisfactory adjustments for the coefficient of determination and, regardless of the model, all had relative mean errors of less than $10 \%$ and an average standard deviation close to zero, the best adjustments found for the Sabbab model.

There are still few works studying the hygroscopic equilibrium of each part of the fruit separately. Because each part of the coffee fruit has a different chemical composition and anatomy, when subjected to separate analyses, the behavior tends to be different. It is important to highlight that such chemical and anatomical differences have a direct influence on postharvest processes, mainly drying, because each tissue of the coffee pericarp and the endosperm offers different resistance to water outflow (Dias, 2017).

Table 5 shows the coefficients of the chosen mathematical model, based on statistical selection criteria, for modeling the sorption isotherms of coffee fruit parts.

TABLE 5. Coefficients of chosen mathematical model, based on statistical selection criteria, adjusted to the desorption isotherms of coffee fruit parts.

\begin{tabular}{|c|c|c|c|}
\hline & \multicolumn{3}{|c|}{ COEFFICIENTS } \\
\hline \multirow{2}{*}{ MODEL } & \multicolumn{3}{|c|}{ EXOCARP + PART OF MESOCARP } \\
\hline & $\mathrm{a}$ & $\mathrm{b}$ & $\mathrm{c}$ \\
\hline \multirow[t]{2}{*}{ GAB modified } & 0.165942 & 59.24550 & 380.7321 \\
\hline & \multicolumn{3}{|c|}{ MESOCARP } \\
\hline \multirow[t]{2}{*}{ GAB modified } & 0.412622 & 24.32445 & 580.3091 \\
\hline & \multicolumn{3}{|c|}{ ENDOCARP } \\
\hline \multirow[t]{2}{*}{ Henderson modified } & 6.919672 & -18.3972 & 4.818797 \\
\hline & \multicolumn{3}{|c|}{ ENDOSPERM } \\
\hline Sabbab & 2.136378 & 0.332360 & 0.202718 \\
\hline
\end{tabular}

Figures 1(A)-(D) show the sorption isotherms of coffee fruit parts, both based on experimental data and on estimated data from the mathematical models offering the best fit, as a function of water content (dry basis) and water activity (decimal). 

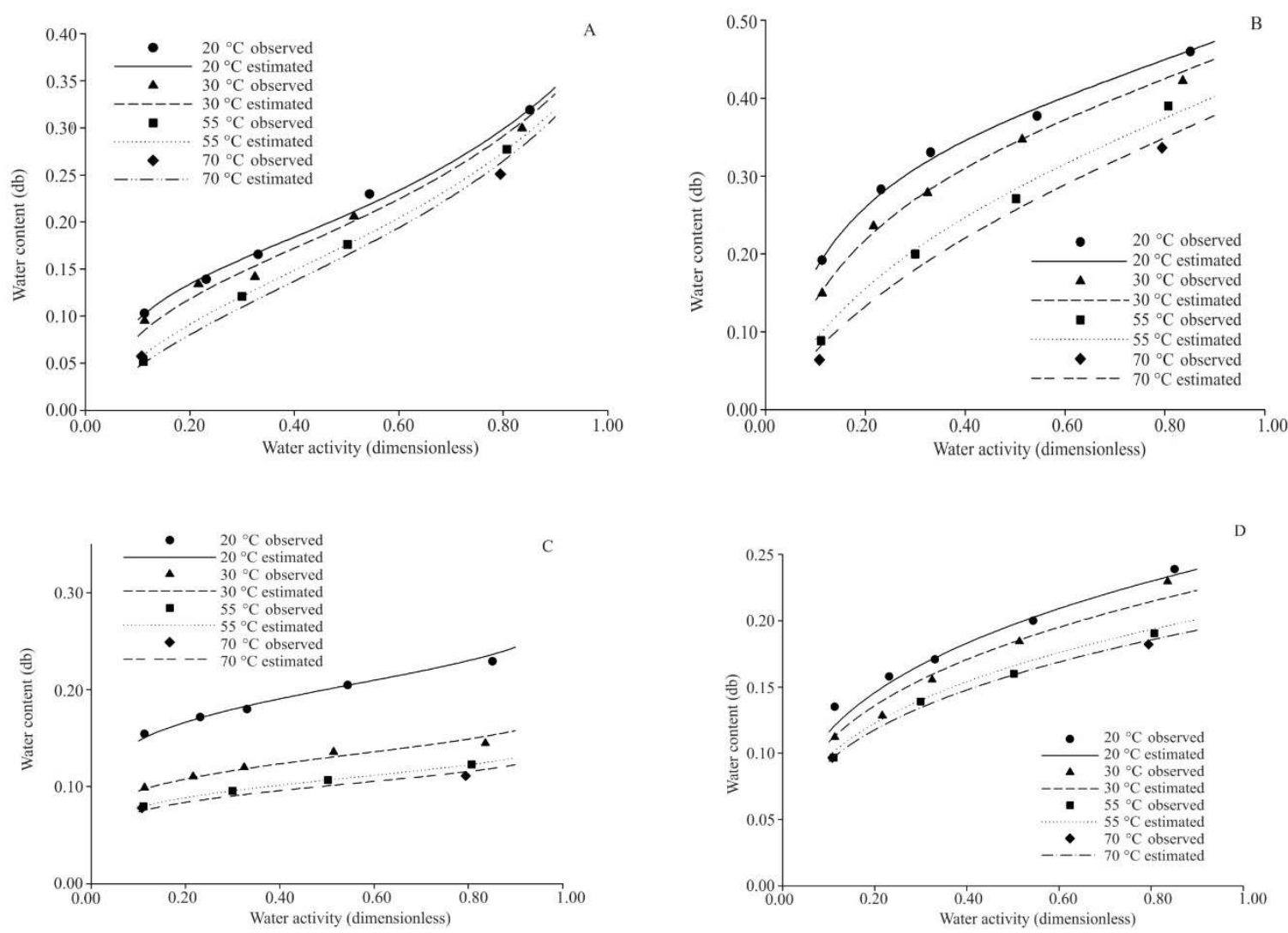

FIGURE 1. Estimated and observed sorption isotherms of exocarp + part of mesocarp (A), mesocarp (B), endocarp (C), and endosperm (D), at $20^{\circ} \mathrm{C}, 30^{\circ} \mathrm{C}, 55^{\circ} \mathrm{C}$, and $70^{\circ} \mathrm{C}$.

The figures show that the models fit the experimental data, in the range of water activity and equilibrium water content analyzed, at the four studied temperatures. Regardless of the coffee part, the temperature increase causes a decrease in the equilibrium water content. The equilibrium water content makes it possible to know the isosteric heat, which is essential in drying and storage studies of agricultural products, enabling one to estimate the energy needs of the drying process, as well as providing data on the water state in the product (Resende et al., 2006b).

An analysis of the sorption curve figures of coffee pericarp tissues and endosperm reveals that the equilibrium water content, in water activities of more than 0.50 , increases more rapidly, resulting in a steeper sorption curve. According to Alves et al. (2015), this results from a weak water bond to food constituents in higher water contents, thus requiring energy close to that required for pure water vaporization. However, when the water activity decreases, the water in the product becomes increasingly bound.

For the same water activity, the equilibrium water content decreases as the temperature increases. According to Rizvi (2005) and Costa et al. (2015), at higher temperatures, the water molecules reach higher energy levels, and this enables them to break with their sorption sites, thus reducing the equilibrium water content. At constant temperatures, the water content increases with water activity values for the sorption isotherms of coffee pericarp tissues and endosperm.

The highest equilibrium water content was obtained by the mesocarp, followed by the exocarp + part of mesocarp, endocarp, and endosperm. This may be because the mesocarp's chemical composition has high levels of sugars, which result in higher water adsorption, unlike the endosperm, which has cellulose, lignin, and hemicellulose as the main chemical components.

The models that best represented the hygroscopicity phenomena were used for the determination of water activity values $\left(a_{\mathrm{w}}\right)$, in the analysis of isosteric sorption heat of coffee pericarp and endosperm tissues. From the calculation of $\ln \left(a_{w}\right)$ values, the curves of the natural logarithm of water activity of coffee pericarp and endosperm tissues were built as a function of inverse absolute temperature $\left(1 / \mathrm{T}, \mathrm{K}^{-1}\right)$. These curves are in Figures 2(A)-(D), for different equilibrium water contents $(\mathrm{db})$, along with their respective linear equations. 

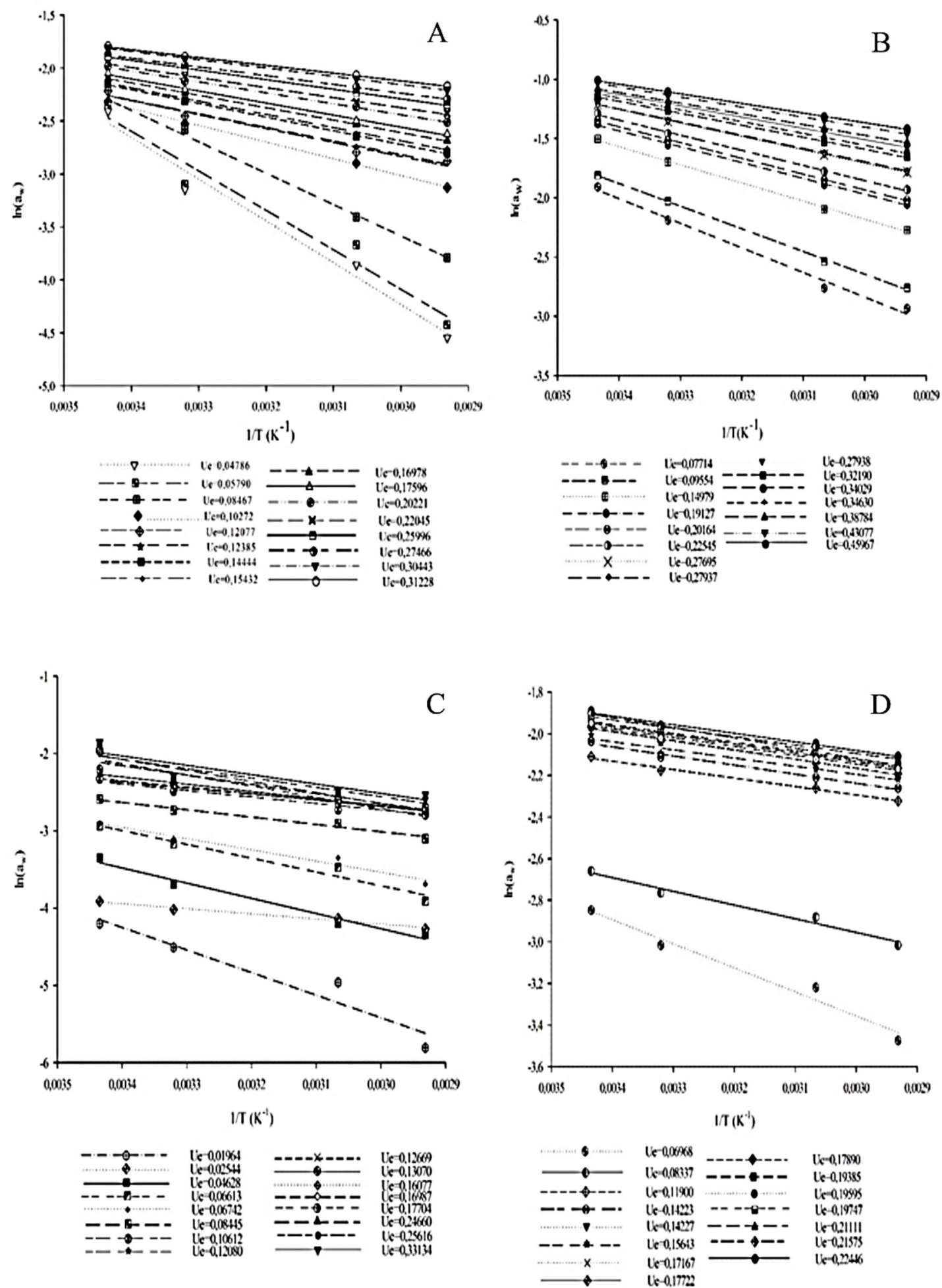

FIGURE 2. $\ln \left(\mathrm{a}_{\mathrm{w}}\right)$ values for different equilibrium water content $(\mathrm{db})$, as a function of water activity ( $\left.\mathrm{a}_{\mathrm{w}}\right)$ and temperature for exocarp + part of mesocarp (A), mesocarp (B), endocarp (C), and endosperm (D)

Net sorption isosteric heat $\left(\mathrm{q}_{\mathrm{st}}\right)$ values were calculated as a function of the angular coefficient. For the determination of the integral isosteric sorption heat $\left(\mathrm{Q}_{\mathrm{st}}\right)$, in $\mathrm{kJ} \mathrm{kg}^{-1}$, represented by Equation (11), the value of free water vaporization latent heat $(\mathrm{L})$, which represents the minimum amount of energy required to evaporate water, was also considered. This calculation considered the average working temperature, which was $43.75^{\circ} \mathrm{C}$, resulting in a latent vaporization heat value of $2397.638 \mathrm{~kJ}$ $\mathrm{kg}^{-1}$. The values of the liquid and integral sorption isosteric heat obtained, respectively, from the angular coefficient and the latent heat of vaporization are shown in Table 6. 
TABLE 6. Liquid and integral sorption isosteric heat values for different equilibrium water contents (db).

\begin{tabular}{|c|c|c|c|c|}
\hline $\begin{array}{l}\text { Equilibrium water } \\
\text { content }(\mathrm{db})\end{array}$ & Line equation & Angular coefficient & $\begin{array}{c}\text { Liquid isosteric heat } \\
\left(\mathrm{kJkg}^{-1}\right)\end{array}$ & $\begin{array}{c}\text { Integral isosteric heat } \\
\left(\mathrm{kJkg}^{-1}\right)\end{array}$ \\
\hline \multicolumn{5}{|c|}{ EXOCARP + PART OF MESOCARP } \\
\hline 0.048 & $y=728.454 x-16.076$ & 728.454 & 336.473 & 2734.110 \\
\hline 0.058 & $y=708.968 x-15.283$ & 708.968 & 327.472 & 2725.110 \\
\hline 0.085 & $y=621.514 x-14.485$ & 621.514 & 287.077 & 2684.715 \\
\hline 0.103 & $y=594.741 x-7.756$ & 594.741 & 274.711 & 2672.348 \\
\hline 0.121 & $y=555.642 x-6.778$ & 555.642 & 256.651 & 2654.289 \\
\hline 0.124 & $y=551.039 x-6.665$ & 551.039 & 254.525 & 2652.162 \\
\hline 0.144 & $y=508.478 x-6.597$ & 508.478 & 234.866 & 2632.504 \\
\hline 0.154 & $y=492.816 x-6.433$ & 492.816 & 227.632 & 2625.269 \\
\hline 0.170 & $y=462.404 x-6.125$ & 462.404 & 213.584 & 2611.222 \\
\hline 0.176 & $y=452.558 x-5.978$ & 452.558 & 209.037 & 2606.674 \\
\hline 0.202 & $y=413.016 x-5.530$ & 413.016 & 190.772 & 2588.410 \\
\hline 0.220 & $y=383.344 x-5.219$ & 383.344 & 177.067 & 2574.704 \\
\hline 0.260 & $y=339.411 x-5.010$ & 339.411 & 156.774 & 2554.411 \\
\hline 0.275 & $y=302.011 x-4.729$ & 302.011 & 139.499 & 2537.136 \\
\hline 0.304 & $y=279.529 x-4.492$ & 279.529 & 129.115 & 2526.752 \\
\hline 0.318 & $y=269.461 x-4.334$ & 269.461 & 124.464 & 2522.102 \\
\hline \multicolumn{5}{|c|}{ MESOCARP } \\
\hline 0.077 & $y=2723.309 x-9.067$ & 2723.309 & 1257.896 & 3655.534 \\
\hline 0.096 & $y=2518.968 x-8.389$ & 2518.968 & 1163.511 & 3561.149 \\
\hline 0.150 & $y=2007.843 x-6.789$ & 2007.843 & 927.423 & 3325.060 \\
\hline 0.191 & $y=1680.859 x-5.994$ & 1680.859 & 776.389 & 3174.026 \\
\hline 0.202 & $y=1619.221 x-5.939$ & 1619.221 & 747.918 & 3145.556 \\
\hline 0.225 & $y=1463.022 x-5.690$ & 1463.022 & 675.770 & 3073.407 \\
\hline 0.277 & $y=1173.056 x-5.104$ & 1173.056 & 541.835 & 2939.472 \\
\hline 0.279 & $\mathrm{y}=1171.420 x-5.036$ & 1171.420 & 541.079 & 2938.717 \\
\hline 0.279 & $y=1161.985 x-5.094$ & 1161.985 & 536.721 & 2934.358 \\
\hline 0.322 & $y=968.410 x-4.627$ & 968.410 & 447.309 & 2844.946 \\
\hline 0.340 & $y=907.796 x-4.502$ & 907.796 & 419.311 & 2816.949 \\
\hline 0.346 & $y=872.267 x-4.552$ & 872.267 & 402.900 & 2800.538 \\
\hline 0.370 & $y=793.666 x-4.351$ & 793.666 & 366.594 & 2764.232 \\
\hline 0.388 & $y=733.775 x-4.193$ & 733.775 & 338.931 & 2736.568 \\
\hline 0.431 & $y=613.267 x-3.938$ & 613.267 & 283.268 & 2680.906 \\
\hline 0.460 & $\mathrm{y}=547.814 \mathrm{x}-3.808$ & 547.814 & 253.035 & 2650.673 \\
\hline \multicolumn{5}{|c|}{ ENDOCARP } \\
\hline 0.020 & $\mathrm{y}=1756.154 \mathrm{x}-14.190$ & 1756.154 & 811.168 & 3208.805 \\
\hline 0.025 & $y=1704.841 x-6.184$ & 1704.841 & 787.466 & 3185.104 \\
\hline 0.046 & $y=1595.913 x-10.168$ & 1595.913 & 737.152 & 3134.790 \\
\hline 0.066 & $y=1474.935 x-9.081$ & 1474.935 & 681.272 & 3078.910 \\
\hline 0.067 & $y=1471.449 x-7.889$ & 1471.449 & 679.662 & 3077.300 \\
\hline 0.084 & $y=1378.355 x-5.838$ & 1378.355 & 636.662 & 3034.300 \\
\hline 0.106 & $y=1273.902 x-6.486$ & 1273.902 & 588.415 & 2986.053 \\
\hline 0.121 & $y=1199.788 x-6.231$ & 1199.788 & 554.182 & 2951.819 \\
\hline 0.127 & $y=1182.413 x-6.393$ & 1182.413 & 546.157 & 2943.794 \\
\hline
\end{tabular}




\begin{tabular}{cllll}
\hline \hline Table 6 (continued) & & & \\
0.131 & $\mathrm{y}=1173.547 \mathrm{x}-6.254$ & 1173.547 & 542.061 & 2939.699 \\
0.161 & $\mathrm{y}=1037.323 \mathrm{x}-6.287$ & 1037.323 & 479.139 & 2876.777 \\
0.170 & $\mathrm{y}=1002.387 \mathrm{x}-6.295$ & 1002.387 & 463.003 & 2860.640 \\
0.177 & $\mathrm{y}=965.902 \mathrm{x}-6.265$ & 965.902 & 446.150 & 2843.788 \\
0.247 & $\mathrm{y}=757.026 \mathrm{x}-6.179$ & 757.026 & 349.670 & 2747.308 \\
0.256 & $\mathrm{y}=715.328 \mathrm{x}-6.193$ & 715.328 & 330.410 & 2728.047 \\
0.331 & $\mathrm{y}=544.122 \mathrm{x}-6.143$ & 544.122 & 251.330 & 2648.968 \\
\hline & & & \\
\hline 0.070 & $\mathrm{y}=3978.029 \mathrm{x}-6.823$ & 3978.029 & 1837.452 & 4235.089 \\
0.083 & $\mathrm{y}=3391.492 \mathrm{x}-4.931$ & 3391.492 & 1566.530 & 3964.168 \\
0.119 & $\mathrm{y}=2259.659 \mathrm{x}-3.509$ & 2259.659 & 1043.737 & 3441.374 \\
0.142 & $\mathrm{y}=1733.469 \mathrm{x}-3.558$ & 1733.469 & 800.689 & 3198.327 \\
0.142 & $\mathrm{y}=1731.469 \mathrm{x}-3.542$ & 1731.210 & 799.646 & 3197.283 \\
0.156 & $\mathrm{y}=1463.049 \mathrm{x}-3.364$ & 1463.049 & 675.783 & 3073.420 \\
0.172 & $\mathrm{y}=1235.249 \mathrm{x}-3.532$ & 1235.249 & 570.561 & 2968.199 \\
0.177 & $\mathrm{y}=1151.249 \mathrm{x}-3.489$ & 1151.146 & 531.714 & 2929.352 \\
0.179 & $\mathrm{y}=1131.734 \mathrm{x}-3.479$ & 1131.734 & 522.748 & 2920.385 \\
0.185 & $\mathrm{y}=1039.920 \mathrm{x}-3.428$ & 1039.920 & 480.339 & 2877.977 \\
0.194 & $\mathrm{y}=942.330 \mathrm{x}-3.415$ & 942.330 & 435.262 & 2832.900 \\
0.196 & $\mathrm{y}=923.726 \mathrm{x}-3.356$ & 923.726 & 426.669 & 2824.306 \\
0.197 & $\mathrm{y}=907.381 \mathrm{x}-3.376$ & 907.381 & 419.119 & 2816.757 \\
0.211 & $\mathrm{y}=778.826 \mathrm{x}-3.307$ & 778.826 & 359.740 & 2757.377 \\
0.216 & $\mathrm{y}=739.480 \mathrm{x}-3.592$ & 739.480 & 341.566 & 2739.203 \\
0.224 & $\mathrm{y}=677.764 \mathrm{x}-3.320$ & 677.764 & 313.059 & 2710.697 \\
\hline & & & &
\end{tabular}

From these data, and using the STATISTICA version 5.0 program, the following equations were obtained that calculate the integral isosteric heat of sorption to the exocarp + part of the mesocarp in [eq. (15)], mesocarp in [eq. (16)], endocarp in [eq. (17)], and endosperm in [eq. (18)], as a function of the equilibrium water content $(\mathrm{db})$ and $43.75^{\circ} \mathrm{C}$ average temperature.

$Q_{s t}=401.838 \times \exp \left(-3.716 \times U_{e}\right)+2397.638$

$Q_{s t}=1740.206 \times \exp \left(-4.205 \times U_{e}\right)+2397.638$

$Q_{s t}=872.795 \times \exp \left(-3.737 \times U_{e}\right)+2397.638$
$Q_{s t}=4099.111 \times \exp \left(-11.516 \times U_{e}\right)+2397.638$

The values of estimated parameters and the coefficient of determination were, respectively, $\mathrm{a}=$ $401.838, \mathrm{~b}=3.716$, and $\mathrm{R}^{2}=0.9948$ (exocarp + part of mesocarp). $\mathrm{a}=1740.206, \mathrm{~b}=4.205$, and $\mathrm{R}^{2}=0.9962$ (mesocarp), $\mathrm{a}=872.795, \mathrm{~b}=3.737$, and $\mathrm{R}^{2}=0.9996$ (endocarp), and $\mathrm{a}=4099.111, \mathrm{~b}=11.516$, and $\mathrm{R}^{2}=0.9994$ (endosperm). Therefore, Figures 3(A)-(D) present the observed sorption isosteric heat and the sorption isosteric heat estimated by Equations (15)-(18), both as a function of the equilibrium water content (Ue), db. 

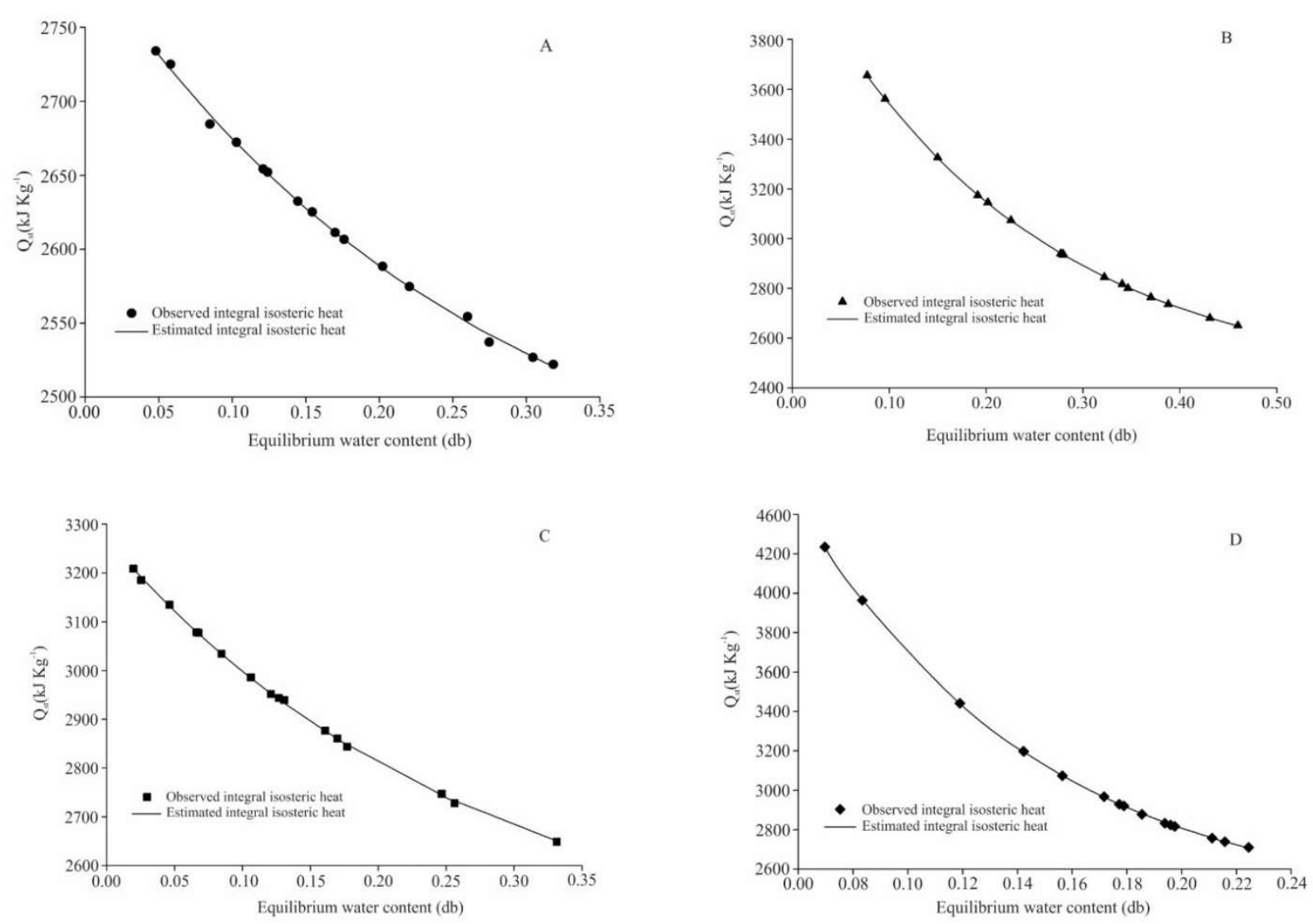

FIGURE 3. Integral isosteric sorption heat $\left(\mathrm{Q}_{\mathrm{st}}\right)$ calculated values from angular coefficients and estimated values, as a function of equilibrium water content for exocarp + part of mesocarp (A), mesocarp (B), endocarp (C), and endosperm (D)

Regardless of pericarp tissue or coffee fruit endosperm, as the product water content decreases, more energy is required for water removal, as observed for various agricultural products, such as beans (Resende et al., 2006a), paddy rice (Resende et al., 2006b), wheat (Corrêa et al., 2005), pistachio nuts (Hayoglu \& Gamli, 2007), chili peppers (Silva \& Rodovalho, 2012), and sugarcane bagasse (Teixeira et al., 2015).

Integral isosteric heat values range from 2734 to $2522 \mathrm{kJkg}^{-1}$ for the exocarp + part of mesocarp, in the equilibrium water content region between 0.04 and 032 (db), from 3655 to $2650 \mathrm{kJkg}^{-1}$ for the mesocarp, in the equilibrium water content region between 0.07 and 0.45 (db), from 3208 to $2648 \mathrm{kJkg}^{-1}$ for the endocarp, in the equilibrium water content region between 0.01 and $0.3(\mathrm{db})$, and from 4235 to $2710 \mathrm{kJkg}^{-1}$ for the endocarp, in the equilibrium water content region between 0.06 and $0.22(\mathrm{db})$.

In the lowest range of water content, between 0.01 and $0.07(\mathrm{db})$, the endosperm needs the highest amount of energy to adsorb water, compared with the other tissues of the arabica coffee pericarp. This is because the endosperm is mainly formed by cellulose and hemicellulose, which are water-insoluble compounds. Therefore, the amount of free water is smaller when compared with the pericarp tissues, and this gives the endosperm a barrier to product energy and mass exchange with air. The chemical composition of coffee endosperm is important in the drying process, because water exchange between the fruit and the environment depends on the predominance of one component or another, given the greater or lesser water affinity with each one of these compounds (Borém, 2013).

Polysaccharides in the coffee endosperm cell wall represent $50 \%$ of the coffee dry weight $(15 \%$ cellulose, $25 \%$ to $30 \%$ arabinogalactan proteins, $50 \%$ mannan and galactomannan, and $5 \%$ pectin). Sucrose is the most abundant among the low-molecular-weight sugars (monosaccharides and disaccharides) and is found in concentrations up to 400 times the combined concentrations of other sugars. Lipids represent $12 \%$ to $18 \%$ of arabica coffee beans, and $75.2 \%$ of these lipids are triglycerides. Protein makes up $9.2 \%$ of the dry weight of arabica coffee beans (Borém et al., 2013).

The results obtained in this study make possible the development of drying technologies or methodologies that provide rapid dehydration without the use of high drying temperatures, especially in terms of reducing drying time.

\section{CONCLUSIONS}

The modified GAB model best described the sorption process for the exocarp + part of mesocarp and for the mesocarp; for the endocarp, the model that best describes the studied phenomenon was the modified Henderson model, and, for the endosperm, it was the Sabbab model.

Regardless of coffee pericarp or endosperm tissue, at the same temperature, increased water activity promoted increased equilibrium water content. For the same water activity, for all studied treatments, the temperature increase caused a lower equilibrium water content.

As the water content decreased, there was an increase in the energy required to remove water from the product for all pericarp tissues and the arabica coffee endosperm. Regardless of the treatment, increasing equilibrium water content resulted in integral isosteric heat decrease, and, because of the anatomical structure and chemical composition, the endosperm required the highest energy to reach the equilibrium water content. 


\section{REFERENCES}

Alves TP, Fóz HD, Nicoleti JF (2015) Isotermas de dessorção de pimentão verde e energia envolvida no processo. Brazilian Journal of Food Technology 18(2):137145. DOI: http://dx.doi.org/10.1590/1981-6723-6114.

Borém FM (2013) Handbook of coffee post-harvest technology. Norcross: Gin.

Borém FM, Garcia Salva TJ, Silva EAA da (2013) Anatomy and chemical composition of the coffee fruit and seed. In: Borém FM (ed). Handbook of coffee post-harvest technology. Norcross: Gin. p. 1-10.

Corrêa PC, Botelho FM, Botelho SCC, Goneli ALD (2014) Isotermas de sorção de água de frutos de Coffea canephora. Revista Brasileira de Engenharia Agrícola e Ambiental 18(10):1047-1052. DOI: http://dx.doi.org/10.1590/1807-

1929/agriambi.v18n10p1047-1052

Corrêa PC, Goneli ALD, Resende O, Ribeiro DM (2005) Obtenção e modelagem das isotermas de dessorção e do calor isostérico de dessorção para grãos de trigo. Revista Brasileira de Produtos Agroindustriais 7(1):39-48.

Costa LM, Resende O, Oliveira DEC, Sousa KA (2015) Isotermas e calor isostérico de sementes de Buchenavia capitata (Vahl) Eichler. Revista Ciência Agronômica 96(3):516-523. DOI: http://dx.doi.org/10.5935/18066690.2015003

Dias CA (2017) Análise da resistência à desidratação dos tecidos do pericarpo e do endosperma do fruto do café. Dissertação Mestrado, Lavras, Universidade Federal de Lavras.

Hayoglu I, Gamli OF (2007) Water sorption isotherms of pistachio nut paste. International Journal of Food Science and Technology 42(2):224-227. DOI:

http://dx.doi.org/10.1111/j.1365-2621.2006.01283.x

Mohapatra D, Rao PS (2005) A thin layer drying model of parboiled wheat. Journal of Food Engineering 66(4):513518. DOI: https://doi.org/10.1016/j.foodeng.2004.04.023

Mulet A, García-Reverter J, Sanjuán R, Bom J (1999) Sorption isosteric heat determination by thermal analysis and sorption isotherms. Journal of Food Science 64(1):1750-3841. DOI: http://dx.doi.org/10.1111/j.13652621.1999.tb09862.x.

Resende O, Corrêa PC, Goneli ALD, Martinazzo AP, Ribeiro RM (2006a) Isotermas e calor isostérico da dessorção do arroz em casca. Revista Brasileira de Armazenamento 31(1):86-94.
Resende O, Corrêa PC, Goneli ALD, Ribeiro RM (2006b) Isotermas e calor isostérico de sorção do feijão. Ciência e Tecnologia de Alimentos 26(3):626-631. DOI: http://dx.doi.org/10.1590/S0101-20612006000300022

Rizvi SSH (2005) Thermodynamic properties of food in dehydration. In: Taylor \& Francis Group (ed). Boca Raton: Engineering properties of food, 3rd ed: p 1-88.

Rosentrater KA, Verbeek CJR (2017) Water adsorption characteristics of extruded blends of corn gluten meal and distillers dried grains with solubles. Food and Bioproducts Processing 101:110-117. DOI:

https://doi.org/10.1016/jfbp.2016.10.014

Silva HW, Rodovalho RS (2012) Isotermas de dessorção das sementes de pimenta malagueta. Global Science and Technology 5(1):32-39.

Simón C, Esteban LG, Palacios P, Fernández FG, MartínSampedro R, Eugenio ME (2015) Thermodynamic analysis of water vapour sorption behaviour of juvenile and mature wood of Abies alba Mill. Journal of Materials Science 50(2):7282-7292. DOI:

https://doi.org/10.1007/s10852-015-9283-7

Simón C, Esteban LG, Palacios P, Fernández FG, GarciaIruela A (2016) Thermodynamic properties of the water sorption isotherms of wood of limba (Terminalia superba Engl. \& Diels), obeche (Triplochiton scleroxylon K.

Schum.), radiata pine (Pinus radiata D. Don) and chestnut (Castanea sativa Mill.). Industrial Crops and Products 94:122-131. DOI:

https://doi.org/10.1016/j.indcrop.2016.08.008

Teixeira LP, Andrade ET, Espíndola JZ, Pereira RG (2015) Determinação do equilíbrio higroscópico e do calor isostérico do bagaço de cana-de-açúcar. Revista Engenharia Agrícola 35(3):555-566. DOI: http://dx.doi.org/10.1590/1809-4430Eng.Agric.v35n3p555-566/2015

Wang N, Brennan JG (1991) Moisture sorption isotherm characteristics of potatoes at four temperatures. Journal of Food Engineering 14(4):269-287. DOI: https://doi.org/10.1016/0260-8774(91)90018-N

Wani SA, Kumar P (2016) Moisture sorption isotherms and evaluation of quality changes in extruded snacks during storage. LWT - Food Science and Technology 74:448-455. DOI:

https://doi.org/10.1016/j.lwt.2016.08.005 